\title{
Curriculum Studies and Indigenous Global Contexts of Culture, Power, and Equity
}

Lasana D. Kazembe, Indiana University Purdue University at Indianapolis

https://doi.org/10.1093/acrefore/9780190264093.013.1591

Published online: 23 February 2021

\begin{abstract}
Summary
For historically marginalized groups that continue to experience and struggle against hegemony and deculturalization, education is typically accompanied by suspicion of, critique of, and resistance to imposed modes, systems, and thought forms. It is, therefore, typical for dominant groups to ignore and/or regard as inferior the collective histories, heritages, cultures, customs, and epistemologies of subject groups. Deculturalization projects are fueled and framed by two broad, far-reaching impulses. The first impulse is characterized by the denial, deemphasis, dismissal, and attempted destruction of indigenous knowledge and methods by dominant groups across space and time. The second impulse is the effort by marginalized groups to recover, reclaim, and recenter ways of knowing, perceiving, creating, and utilizing indigenous knowledge, methods, symbols, and epistemologies. Deculturalization projects in education persist across various global contexts, as do struggles by global actors to reclaim their histories, affirm their humanity, and reinscribe indigenous ways of being, seeing, and flourishing within diverse educational and cultural contexts. The epistemologies, worldview, and existential challenges of historically marginalized groups (e.g., First Nations, African/African American, Latinx, Asian, and Pacific) operate as sites and tools of struggle against imperialism and dominant modes of seeing, being, and making meaning in the world. Multicultural groups resist deculturalization in their ongoing efforts to apprehend, interrogate, and situate their unique cultural ways of being as pedagogies of protracted resistance and praxes of liberation.
\end{abstract}

Keywords: global education, deculturalization, culture, curriculum, educational equity, indigenous, epistemology, cultural memory

\section{Epistemological Struggles Across Global Contexts}

Nearly 45 years ago when it was published, the widely cited critique of U.S. schools and educators by Samuel Bowles and Herbert Gintis (1976) shed important light on pervasive inequality, repressiveness, contradictions, and long-standing tensions framing education and curriculum discourse. A key aspect of their analysis involved a critique of the sociopolitical context in, by, and through which education is developed, organized, and managed. This braided context is scaffolded by a fierce, hierarchical system of educational "have-gots" and "have-nots" that eschews multicultural, democratic impulses in favor of monocultural, elitist 
ones. Under and through such conditions, the lived realities of subject peoples are orchestrated and policed with intense scrutiny. This is especially the case among historically marginalized and minoritized groups existing and struggling within multiple global contexts. For such peoples (i.e., I/indigenous, African/African American, Latinx, and Asian), equitydriven educational and political projects coincide with foundational struggles to survive organically, to reimagine themselves, and to reclaim and reproduce cultural ways of knowing and being. (NOTE: I/indigenous is used throughout the article and references two distinct meanings. Uppercase "Indigenous" acknowledges the political struggles over cultural identity and sovereignty of First Nations peoples. Lowercase "indigenous" is used as an anthropological term to acknowledge human groups that originate in a particular region of the world.).

As an offshoot of broader, centuries-long colonial projects, deculturalization processes aimed at marginalized and minoritized groups reverberate across centuries and continue to have an adverse impact on the lives and futures of these groups. This is especially evident within education where proponents for educational equity continue to encounter extreme resistance to efforts to more fully interrogate, challenge, and dismantle dominant metanarratives around remembered history, knowledge production, pedagogy, and the basic function of education. For Dei, Hall, and Rosenberg (2000), globalization has not only produced a "crisis of knowledge" (p. 3) but has stimulated intensified campaigns of deculturalization, knowledge hierarchies, and assaults on I/indigenous claims to agency, historiography, language sovereignty, and psychocultural liberation. Indeed, during the last half-century, governmentimposed austerity and authoritarianism-linked to massive economic and demographic shifts occurring around the globe-have given rise to new forms of social oppression, wage/labor exploitation, tribalism, and xenophobia.

Within the United States, for example, H.R. 2281 represents a most spectacular case of a targeted assault on indigenous education and democratic principles. That 2012 Arizona state law banned the teaching of ethnic studies and, according to Arizona Attorney General Tom Horne, sought to ensure "that public education is not held captive to radical, political elements" (Carcamo, 2013). More acutely, the law targeted the Mexican American Studies (MAS) program, a high school curriculum co-developed by Tucson Unified School District and University of Texas at San Antonio (UTSA). During and since its inception, MAS has faced intense resistance, budget cuts, and hyperscrutiny over its curriculum which detractors describe as advocating ethnic solidarity. As of 2017, the law banning ethnic studies was overturned by a federal judge who found that it was motivated by racial discrimination and violated pupils' constitutional rights. As frequent targets, marginalized and minoritized groups of color have borne the brunt of these assaults while simultaneously continuing their centuries-long (in most cases) struggles to redefine and reclaim their histories, and to situate themselves within their respective global communities as students, workers, and citizens.

As Spring (2010) writes, "deculturalization is the educational process of eliminating cultures" (p. 1). The educational challenges of dominated cultures supersede $2+2$ and neutral curriculum studies formations. Rather, their educational challenges align with broader, infinitely more complex sociopolitical and sociocultural challenges such as protection of language, culture, and collective memory. The linked goals of this article are twofold: (a) to provide a brief survey of deculturalization projects in education across global contexts and (b) to locate and link contemporary struggles for equity and reacclimation by global actors to reclaim their histories, affirm their humanity, and reinscribe I/indigenous ways of being, 
seeing, and flourishing across their particular educational contexts. Though the article's goals are inextricably linked, it is important that the lives and cultural agency of I/indigenous peoples not be viewed through an endless analysis of dominance but rather interrogated and valued for their unique contribution to pedagogies and praxes of liberation, to Indigenous notions of modernity, and to the tapestry of human experience.

\section{Assaults on History and Memory}

With roots stretching back as early as the 4th century, Tibetan culture is unique in its efforts to preserve and maintain its major features (i.e., a functional Buddhist theocracy, linguistic system, and cultural ethos) while resisting disintegration from external forces. Modern Tibetan culture has been shaped, in large part, by the country's loss of independence, as well as the disintegrating influences of Chinese-imposed colonialism, modernization, and educational structures. Within the Tibetan Autonomous Region (TAR), this cultural imposition is most strongly evidenced by China's bilingual education policies.

Throughout the last two centuries, the culture, language, and collective memory of Indigenous (First Nations) groups within the United States and Canada have been subverted, minimized, and (in many cases) literally removed from national historical memory of citizens of those respective countries. Among the Indigenous, efforts to reconstruct themselves (and their histories), as well as to control how they are remembered and portrayed, continue to be met with fierce resistance whether the contested terrain is the classroom or the sports entertainment complex. The indigenous case mirrors the African case wherein foreignimposed language and colonial classrooms are leveraged as tools of psychological conquest. African writers such as Thiong'o (2009) are among the major voices in ongoing discourses over African language revival and preservation, historiography, and rhetorical sovereignty.

With over 80 indigenous languages spoken across 105 native groups, Colombia remains a fierce front for a centuries-long struggle on behalf of the Indigenous to reclaim their ancestral lands, and to recover and retain their cultures, languages, and communal values. As they struggle against a state-driven educational system seen by many as top-down and decontextualized, former and current generations of Colombians have critiqued their system for its rigid deemphasizing of indigenous history and cultural remembering, and for subjecting them to what many interpret and describe as cultural genocide.

For Black Americans, themselves the progeny of enslaved Africans, the assault on their history and memory predated their arrival during the early 1500s in what became the United States. Thus, across a period of more than 500 years, the Black struggle for education has evolved coterminous with the early development of the United States, its capital and cultural formation, its pluralistic makeup, and its democratic aspirations (real and alleged). Though meted internationally, neoliberal reforms and policies framing U.S. public education have had an especially disruptive impact on entire generations of Black children and families. This group continues to struggle against deculturalization in education and feels its effects in the forms of privatized schools and services, public school turnovers and closures, charter schools, austerity, high-stakes standardized testing, chronic school leadership turnovers, and hypersegregation. 
The impact of deculturalization produces a variety of tragic outcomes for I/indigenous, Black, Latinx, and Asian populations: amputated memory; disruption of traditional values and beliefs; distortions of I/indigenous histories and assaults on ecosystem and modes of communal living; interruption of cultural rhythms, ways of perceiving, knowing, and valuing; and trans- and interracial tensions related to efforts on behalf of I/indigenous groups to remember, reclaim, and reinscribe themselves (Dei et al., 2000, p. 4). For the oppressed, the deculturalization process presents an existential and ontological dilemma wherein I/indigenous subjectivity is viciously disrupted, rechanneled, and directed through the gaze of the oppressor. In such cases, affected groups come to experience their identity not through a locus of self-respect and self-affirmation but through a locus of imposed subjectivity and ideological imperialism. Within the imposition, I/indigenous identities often develop in tandem with a dialectic of performativity/resistance in which the targets of deculturalization are invited to identify and disidentify simultaneously. The oppressed, then, are coerced to perform oppression using their bodies, reconditioned subjectivities, and fragmented memories in a context that Fanon (1967) describes as the body being "surrounded by an atmosphere of certain uncertainty" (pp. 110111).

For centuries, the problematic legacy of deculturalization and miseducation of Indigenous Australians has been reflected by the European colonial government's efforts to physically exterminate and/or assimilate the Indigenous. For over 200 years and counting, Indigenous Australians (not unlike the Indigenous peoples of North America) experienced systematic and wide-scale frontier violence that took the form of shootings, poisonings, torture, land theft, and child kidnappings (Brady, 1997). For six decades (1910-1970), over 100,000 Aboriginal and Torres Strait Islander children (known as The Stolen Generations) were forcibly taken from their families and transported hundreds of miles to reservations or missionary schools. There, they were subjected to a curriculum that trained them to despise, reject, and ultimately abandon their indigenous heritage and to adopt White (British) culture and folkways. More than simply being forced to adopt the alien European culture, Indigenous Australians were systematically trained to regard it (and European people) as superior and their own culture and selves as inferior. In modern-day Australia, strategies to implement antiracist and culturally responsive education within an overcrowded curriculum are often forestalled by efforts to intentionally forget and/or whitewash the most contentious aspects (e.g., Indigenous massacres) of Australia's excessively violent colonial past (Reynolds, 2006).

The philosophy and practices of deculturalization are rooted in diverse forms of physical and psychic violence, power inequities, and imposed relations between colonizer and colonized. As a process, deculturalization is mediated through history, culture, and human contact, as well as through the fragile channels of human remembering (and unremembering). Deeply embedded within deculturalization practices is a hidden curriculum violence of alienating the oppressed from their natural selves and ultimately encouraging the oppressed to feel comfortable with being dominated and alienated. Toward this end, a specific type of mass miseducation becomes politically necessary in order to appropriately subdue and socialize current and successive generations. Genocidal effects, then, of centuries of direct/indirect European rule on I/indigenous groups globally have found their strongest, psychocultural expression in the perpetuation of media stereotypes, racial-religious imagery, and formal school curricula to which I/indigenous children and families are exposed. Santos (2014) 
employs the term "epistemicide" to describe the process of silencing and displacing of I/ indigenous knowledge systems and replacing them with foreign knowledge systems rooted in and propelled by politically and culturally hegemonic policies, practices, and processes.

Linking to Santos (2014), Asante (2017), Du Bois (1903, 1973), Spring (2010), Thiong'o (2009), and Woodson (1933) have written about the stupefying and narcotizing effects of dominant group-imposed education and its tendency to hamper the history, culture, agency, and generational memory of subjugated groups. Expounding deeper on psychocultural effects of deculturalization, Baldwin (1980, 1984, 1985, 1989), Kambon (2003), Wilson (1993), and other scholars have explored its role in forcing the oppressed to accept and live with racial subjugation, racial-cultural contradictions, and psychological misorientation as normal features of everyday life. As these "normalized" aspects of life remain unquestioned or unchallenged, efforts on the part of the dominated to reacculturate themselves are often met with hostility and curiosity. Owing to the impact of deculturalization across time and space, members of dominated cultures will themselves often regard reacculturation efforts as not only unachievable but inconceivable. For the dominated, then, a chief outcome of deculturization is the interruption of the mind's teleological capacities. As Kambon (2003) avers, the minds of the oppressed are biased, shaped, and influenced in terms of imposed history, internalized worldview, and cultural misorientation (pp. 36-39). Operating as and feeding a vicious cycle, deculturalization serves to stifle or nullify I/indigenous knowledge systems and memory and to diminish the capacity to bring about equity, pedagogical liberation, and social transformation.

\section{Assaults on Human Agency}

A fundamental flaw in modern Western thought and materialist practices is its formulation within and alongside essentialist claims (i.e., modern, democratic, civilized, scientific, and Christian) which doubt, deny, distort, destroy, and/or ignore the human beingness of I/ indigenous/Black/Latinx; privilege, value, normalize, and situate White ontology/identity as predominant; and position European/Euro-American agents, systems, institutions, ideologies, and thought forms as compulsory engines of progress. Within this perspective and practice, the radical imagination is arrested and substituted with devalued, pseudo-intellectual, subjectivist stances rooted in ersatz notions of White superiority.

Along with the negation of human agency and the "deliberate destruction of other cultures," colonial domination seeks to position certain peoples in ways that support knowledge "hierarchies that justify domination, oppression" yet blame the oppressed for possessing cultural deficiencies that make their domination necessary (Santos, 2016, p. 18). Regarded as subaltern (at best), or nonexistent (at worst), the human agency of subject peoples is located in a kind of stasis while the culturally mediated artifacts of human agency (i.e., ancestral vision, collective knowledge, folk wisdom, spiritual moorings, and affirming myths) become frozen in time and place. One's agency (and its liberating possibilities), therefore, goes unnoticed, unrealized, and unnourished. An often tragic end result of these assaults on human agency is ontological decentering, cultural uncoupling, and generational estrangement from the humanity that makes one human and the diversity that makes one distinct. 
For those on the receiving end of deculturalization processes (and attendant oppression and domination), reeducation projects go hand in hand with liberatory praxes that acknowledge, affirm, and assert humanity, identities, and citizenship. Across global contexts, failure, reluctance, and/or unwillingness to acknowledge and arrest ideologies, discourses, and practices (curricular or otherwise) that negate the humanity of I/indigenous peoples is designed to reinforce and extend the reign of White supremacy. Power wielded by dominant groups is able to be maintained and expanded relative to the degree to which subject peoples do not resist, challenge, or work to dismantle educational hierarchies, social arrangements, and cultural inequity. Alternatively, ideologies, modes of inquiry, discourses, and practices that affirm and promote I/indigenous humanity reflect liberatory, antihegemonic stances rooted in justice, civility, morality, and humaneness.

In their research on historical dehumanization and contemporary consequences, Goff, Eberhardt, Jackson, and Williams (2008) frame dehumanization as "a method by which individuals and social groups are targeted for cruelty, social degradation, and state-sanctioned violence" (p. 305). Haslam (2006) suggests that two distinct yet related forms of dehumanization are operationalized by dominant groups against subordinated groups and their human agency. Both forms involve the "denial to others of distinct senses of humanness" (p. 252). One form is referred to as animalizing; the second form is referred to as mechanizing. Animalizing refers to the ascribing of animal (i.e., nonhuman) characteristics to human beings while simultaneously denying the natural characteristics that make them uniquely human. In one of his more potent anti-immigrant(ion) rants, U.S. president Donald J. Trump channeled the long history of dehumanization when he referred to Mexican immigrants as animals. Sadly, one can draw profound similarities between caged Mexican children in the 21st century and interned Native American children in the 20th century. To borrow the observation of anthropologist Oliver La Farge concerning conditions at U.S.-developed Indian schools, one can safely conclude that groups of little children are targeted to "expiate the crime of being born of their mothers" (Spring, 2018, p. 24).

Relatedly, mechanizing refers to the denial and/or negation of natural senses and attributes that typify human nature and the reduction of human beings to the level of tools and emotionless utilitarian objects. When applied to the existential experience of Black people in the United States, for example, Haslam's perspective on dehumanization is simultaneously refined and expanded as it (a) becomes racialized and (b) typifies the everyday lived reality of Black Americans and the sociopolitical and sociocultural development and propagation of Western ideology, institutions, thought forms, and materialist practices. Within education, the rampant growth of for-profit schools has led to what many decry as an increasingly depersonalized, technocratic system that favors profits over people and promotes a soulless model that aims to mechanize human thought. Within the United States and developing countries, the corporate architects of neoliberal education reforms promote and favor pedagogical formations (e.g., curriculum development, teacher preparation, education policy, and assessment) that are decontextualized and deculturalized in order to produce docile workers who are depoliticized, ahistorical, and noncritical. These masses, though not required to think/question critically or mobilize, are expected to serve the profit-seeking motives of corporatists, privateers, and transnational corporations. 
One tragic (and ongoing) example of the assault on the human agency of Black Americans is what the author calls "racialized surrogacy." In one specific context, this term refers to the chronic, obsessive targeting and exploitation of Black women's bodies. Hence, with racialized surrogacy, Whites have (through the centuries) grimly imposed upon the humanity of Black women and girls by subjecting them to abuses that have included rape, torture, breeding, public spectacle, and medical experimentation. During the enslavement period in the United States, for example, several generations of Black women and girls were victims of systematic rape and reproductive abuse by being impregnated and forced to have and care for babies that they neither wanted nor wished for. Similarly, during that same period and well into the late 1950s, Black women were frequent, unwilling patients and test subjects for White gynecologists, amateur scientists, and reproductive health practitioners. During late Spring 2018, a statue honoring the so-called father of modern gynecology, J. Marion Sims, was removed from New York's Central Park. Sims, a southern-born slaveholder whose name and likeness is memorialized in medical textbooks and on statues, is on record as having performed hundreds of surgeries on enslaved Black women without anesthesia and without their consent.

Not confined to a few individuals, projects to monetize and dehumanize Black Americans reached its zenith in the United States during the 1900s. Those alive during the U.S. postbellum period (roughly two short decades following the enslavement period) were direct witnesses to the development and popularity of human zoos. Innocuously referred to as "ethnological expositions," human zoos were first conceived in Europe before gaining popularity in Mexico and then in the United States. Indeed, their popularity in London, Italy, France, Germany, and the Netherlands most certainly fueled their popularity in the states, as they formed one of the earliest venues for mass entertainment. Africans such as Ota Benga (brought to the United States in 1904 from Congo Free State by American businessman Dr. Samuel P. Verner, and later caged alongside apes in the monkey house at the Bronx Zoo in New York city) were often put on display alongside American Indians and Pacific Islanders. It is interesting to note that Benga's story picks up roughly 40 years after slavery was abolished in the United States. In fact, the subjugation of Ota Benga can rightly be seen as flowing from earlier, broader instantiations of anti-Blackness and racialized dehumanization of Black Americans. For centuries, the U.S. public (particularly its education, religious, and scientific sectors) has been aggressively socialized into believing in the inherent inferiority of Indigenous and Black peoples and that their ontology resided somewhere outside the zone of humanity. In all cases, human zoos consisted of I/indigenous peoples (so-called primitives) put on display in a pseudo-natural state for the stimulation and commercial amazement of onlookers. The racial theories of European naturalists, biologists, philosophers, and pseudoscientists intersected with those of their Euro-American counterparts to fuel a dogma of deculturalization that has been propagated steadily from the Age of Enlightenment to the present day.

In their study of dehumanization, Kteily, Bruneau, Waytz, and Cotterill (2015) examined empirical root causes of blatant dehumanization within three countries. In one activity, study participants (mostly White Americans) were asked to analyze "ascent of man" silhouettes and asked to rank where they perceived diverse ethnic groups from lower apes to evolved human beings. Not surprisingly, Europeans and Japanese were rated as "similarly evolved" with the study participants. However, Mexican, Chinese, and South Korean immigrants were rated as occupying a lower rung of humanity. Respondents rated Black Americans, Arabs, and Muslims 
as being the least evolved compared with White Americans. Through careful, critical examination of deculturalization processes levied against I/indigenous peoples, and with regard to persistent efforts to deny their human agency, much can be gleaned from deculturization projects across broader global contexts, as well as from ongoing I/indigenous campaigns of critical resistance, radical historical rescue, and cultural reconstruction. Educational projects borne within the context of deculturalization have tended to exclude, silence, and marginalize I/indigenous populations and epistemologies. To forge a productive path forward, I/indigenous groups have found it necessary to engage an affirmative revisioning and acculturation of knowledge systems, methodologies, and frameworks that move beyond witnessing and critique and toward reclamation and restoration.

\section{1/indigenous Possibilities and Radical Promises}

Given the fluidity of culture, the dynamics of human nature, and the weight of history, it will always be necessary to engage discourse and practice around decolonizing education, curriculum, and knowledge. For cultures under domination, in particular, the road to liberatory education is driven by their relative ability to critically problematize history while interrogating the precarious present and recovering and reinscribing remembered histories to work toward positive transformation. Doing so requires that I/indigenous educational methodologies, curricular frameworks, cultural artifacts, and ancestors be consistently acknowledged and authentically situated (centered) within one's philosophy, mindset, and humanizing zones of praxis. And while cultural homeostasis may be a distant goal, it is a worthwhile one for minoritized and marginalized groups that must undertake the commitment to reclaiming and reinscribing their histories, memories, and human possibilities.

The 1970s witnessed the surge and expansion of the U.S. civil rights movement from the U.S. Black community into Native American, Latinx, and Asian American communities. Among Kanaka 'O'iwi (native Hawai'ians), the civil rights movement bolstered their existing, protracted political struggle for economic and environmental justice, higher wages, and overall quality of life. As the struggle evolved, it led to the 1978 Hawai'i State Constitutional Convention which addressed all areas of Indigenous life, including educational sovereignty. The convention laid the basis for the establishment of Ka Papahana Kaiapuni ' $\mathrm{O}^{-}$lelo Hawai' $\mathrm{i}$, Hawaiian language K-12 immersion schools which were developed to "promote the study of Hawaiian culture, history, and language" in all public schools (McGregor, 2010, p. 317). Article X, Section 4 of the revised constitution calls for the inclusion of kupuna or Hawaiian elders to serve as educational specialists and teachers of culturally responsive curriculum in elementary public schools (Hawai'i Const., Art. X, Pt. IV).

As Native Hawaiians activated their Indigenous cultural frameworks to develop an educational model in the long struggle against U.S. settler colonialism and empire, many critical American Indian scholars have embraced Indigenista as a cultural site of critical resistance, acculturation, and educational theorizing. Premised in anticolonial frameworks and practices that name and reject epistemic violence (particularly the process of "othering"), Indigenista centers native language and history as cultural referents that promote educational and pedagogical sovereignty (Grande, 2015). As they interrogate and activate Indigenous modes and traditions of intellectualism, Indigenous communities come to realize their restorative power to address historical and ongoing existential crises. Within education, the 
critical perspectives, methodologies, and voices of Indigenous scholars are necessary in order to expand discourse and practice in classrooms, communities, and other spaces. As sites of struggle, Indigenous education movements are built on frameworks of resistance and survivance yet rooted in philosophies and praxes of remembrance (i.e., investigating and reclaiming what has been lost to memory). Grande (2015) asks, "What does it mean to be a people, a tribe, a community? What does it mean to be Indigenous?" (p. 69).

Two of the most devasting outcomes of deculturation is what scholars have termed "linguistic genocide," or linguicide, and "linguistic famine," or linguifam (Thiong'o, 2009). Both outcomes are the tragic result of I/indigenous peoples' centuries-long encounters with hegemonic, disruptive colonial apparatuses across multiple global contexts. For their part, having long recognized the cohesive value of language, I/indigenous peoples have also come to leverage it as a central instrument of power in their diverse struggles to redefine, restore, and foreground their collective histories, cultures, materialist practices, and ways of meaningmaking.

In 2015, the United Nations General Assembly adopted a new resolution entitled Transforming Our World: The 2030 Agenda for Sustainable Development. Encompassing 17 Sustainable Development goals and 169 targets, this initiative underscores a commitment on the part of the international community to ensure that "all human beings can fulfill their potential in dignity and equality in a healthy environment" (p. 4). Across I/indigenous education contexts, the 2030 agenda reflects the U.N.'s Sustainable Development Goal 4, which promotes renewed distribution of learning opportunities, greater recognition and legitimation of I/indigenous culture and knowledge systems, and leadership roles within public policy. Recognizing the crucial role of languages in human development and cultural flourishing, as well as the need for cognitive and epistemic justice on behalf of I/indigenous peoples, the United Nations declared 2019 the International Year of Indigenous Languages.

A little over 10 years following its adoption of a bilingual education policy, the government of Singapore launched the Speak Mandarin Campaign (Lim, 2020). Developed in 1979, the initial goals of the campaign were to simplify the language environment, to simplify communication among Chinese Singaporeans representing various dialect groups, and to develop a Mandarinspeaking environment to support the government's bilingual education policy. The campaign has evolved over time with an expanded focus that includes widespread promotion of Chinese culture, particularly among Chinese Singaporeans. As part of the new focus, the campaign was renamed the Promote Mandarin Council and reframed to heavily target English-educated Chinese Singaporeans and to stimulate wider appreciation of Chinese culture, traditions, and history. The project has faced criticism from those who complain that it imposes an additional burden on dialect speakers whose children have to now study two foreign languages (Mandarin and English). Also (particularly owing to the project's newer focus), some critics have charged that the project functions as an assimilationist tool that has created a generational linguistic divide between younger Mandarin speakers and their older dialectspeaking relatives. Moreover, as the program continues, concerns have emerged among linguists, historians, educators, and others over the preservation of traditional Chinese dialects. As a mass education campaign of acculturation via language, this project is in its 41st year of existence and has succeeded in changing language habits of Chinese 
Singaporeans through a variety of methods, including telephone-based Mandarin lessons, school curricula, websites, family talent competitions, films, comic strips, and smartphone apps.

Home to over 600 indigenous groups, the peoples of Latin America and the Caribbean have been historically underserved by economic, political, and education systems that have sought to continue centuries-long cycles of deculturization and epistemicide. This has resulted in deeply entrenched epistemic violence, systemic assaults against human agency, and massive underrepresentation of indigenous voices in all levels of education, including policy. For communities struggling to exist in this part of the world, combatting epistemic otherness has meant drawing from and building on indigenous knowledge, values, and practices in order to improve education, as well as overall quality of life and life pathways for these multicultural, multiethnic populations. Within this context (as well as other global contexts), incorporating indigenous knowledge into "standard" practices and education policies is compulsory for building and sustaining systems that prioritize equity, social justice, and human development. In Bolivia, for example, multiple indigenous groups work in concert with the Ministry of Education to produce what is referred to as a Regionalized Curricula that is used across the country's plurinational educational system (United Nations Educational, Scientific and Cultural Organization, 2017). Within a given region of Bolivia, individuals occupying various social roles (e.g., laborer, elder, and wise person) as well as representatives from community organizations contribute ideas to develop proposals that incorporate existing indigenous knowledge systems. This holistic approach to education functions in two major ways: (a) as a strategy for the rescue and recovery of indigenous ways of knowing and meaning-making and (b) as an organic and organized curricula featuring plans, objectives, content, assessment criteria, and so on that draw on, express, and harmonize the sociocultural and linguistic richness of Bolivian indigenous cultures.

Though existing in Latin America since the 1930s, Ecuador's Model of Intercultural Bilingual Education (MOSEIB) came to prominence during the 1980s and has been at the center of that country's struggle for indigenous schooling. As a core part of the country's national education system, MOSEIB emphasizes a curriculum that is culturally and linguistically responsive to Ecuador's 14 indigenous nationalities. Since the 1980s, the country's MOSEIB-based education system has expanded to over 2,500 schools and has trained over 10,000 Indigenous teachers, planners, and administrators (United Nations Educational, Scientific and Cultural Organization, 2017). Following the 2013 Citizens' Revolution, the Republic of Ecuador created the National Plan for Good Living (Republic of Ecuador, 2013) to supplement its national education initiatives. Beyond education, however, the plan boasts full-spectrum policy recommendations and action steps to address pressing social issues including undernutrition, employment, illiteracy, infant mortality, and economic development. A core aspect of the plan is its incorporation of recovered indigenous judicial systems as a means of bringing about regional and interregional transformation, as well as moving closer to human rights-based approaches to social living. An important point that must always be borne in mind is that Ecuador, like all Latin American nations, is still experiencing the effects of three centuries of European (Spanish and Portuguese) colonization and deculturalization projects. Racial stratification, intraracial identity crises, and colorism are but a few of the many postcolonial challenges faced by the Republic of Ecuador. As Ecuador (and other Latin American countries) seeks to restructure a society built on participatory democratic justice and indigenousness, darker-skinned Afro-Ecuadorians (Afro-Peruvians, Afro-Bolivians, etc.) typically find 
themselves relegated to the fringe of the fringe of society. In that sense, perhaps a good register of the social, economic, and political health and progress of these countries would be to monitor the degree to which its most severely disenfranchised and exploited citizens (usually darker-skinned individuals) are able to function and thrive.

Throughout the world, educational access is denied to 61 million children who are out of school and to 775 million adults who are unable to read and write. UNESCO's Education for All (EFA) is a movement that reflects its global commitment to provide quality basic education for all children, youth, and adults. After undertaking a comprehensive assessment of its challenges and opportunities, Senegal adopted the Dakar Framework for Action, Education for All (United Nations Educational, Scientific and Cultural Organization, 2000) during the World Education Forum held in Dakar during April 2000. This long-term, country-wide initiative acknowledges that education is a basic human right, that quality investment in education for all Africans is compulsory, and that high-quality education at all levels is the collective responsibility of government, civilians, and all stakeholders interested in a viable future for Africa and her people. Now in its 20th year, the Dakar Framework was conceived as part of a broader African Renaissance sprung from hard-won victories over colonialism, apartheid, oppression, and economic exploitation. African indigenous methodologies, knowledge systems, cultural heritages, languages, and values are at the core of the Dakar Framework for Action, and are strategically designed and implemented to leverage newer forms of knowledge and information technology. To advance its vision for a humanizing, transcendent society, architects of the Dakar Framework have positioned education at the forefront of a strategic mission that leverages human, material, environmental, and cultural resources to advance the interests of Senegal (in particular) and Africa (in general).

\section{I/indigenous Peoples' Struggle to Right/Rewrite Themselves}

This article has sought to provide a brief historical overview of the impact and aftermath of deculturalization projects across multiple global contexts. A second major aim was to discuss diverse efforts undertaken by I/indigenous groups in their centuries-long struggles to recover and reconstitute their histories, memories, cultures, languages, and epistemologies. The article examined the sociopolitical and psychocultural struggles of I/indigenous groups within various countries (United States, Tibet, Canada, Colombia, Australia, Hawai'i, Singapore, Bolivia, and Ecuador) and discussed distinct ways that these groups are excavating and leveraging I/indigenous practices, methodologies, and knowledge systems to combat deculturization and cultural hegemony. A clear constant that emerges across the various global contexts is the absolute reality that historically marginalized I/indigenous groups must -even in the midst of continuous physical, cultural, and psychological onslaughtscontinuously locate and leverage innovative ways to remember their histories, recover their cultural memories, and reinscribe both in order to positively transform themselves and their societies.

Within a chronological context, the tripartite mission of deculturization has been to obscure the past, confuse the present, and eclipse the future of dominated peoples. Those impacted by deculturization witness and feel its stupefying effects across multiple generations, and across time and space as they are forced to live with (and make sense of) ongoing racial subjugation, racial-cultural contradictions, and psychological misorientation. Concurrently, as they seek to 
right the wrongs of history, the oppressed seek also to right themselves in order that current and successive generations are able to benefit from a cultural equilibrium. For millennia and prior to their various colonial and hegemonic encounters, I/indigenous cultures have maintained themselves via intimate adherence to their traditions, folk wisdom, cultural symbols, and other epistemological practices that were grounded in their respective historical realities. The resultant methodologies and systems of knowledge were apprehended and conveyed via I/indigenous spiritual, interpersonal, and institutional channels and frameworks (i.e., educational, political, and economic). To right themselves, I/indigenous peoples have realized the necessity of recovering, reclaiming, and remembering crucial aspects of their collective historical past. Integrating I/indigenous knowledge, resisting and challenging assimilation, and affirming their humanity are critical steps that I/indigenous peoples must constantly undertake in order to rewrite themselves into history and into the future. The struggle for education, epistemic justice, and social transformation coincides with I/ indigenous peoples' struggles to survive and reproduce themselves.

With due deference to the incalculable impact of deculturalization across various historical (e.g., Transatlantic Slave Trade, colonialism, missionary schools, theft of ancestral lands, deforestation, and mass killings) and topical (e.g., postcolonialism, globalization, miseducation, neoliberalism, racial terrorism, patriarchal Eurocentrism, and mass killings) contexts, I/indigenous peoples across multiple global contexts continue to endure assaults to their human dignity and agency. As they continue to simultaneously struggle against and work within hierarchies that justify domination and oppression, I/indigenous groups are also tasked with interrogating and extrapolating their knowledge, theoretical frameworks, and thought modes in real time. Such work is translated as necessary acts of political resistance and mandatory projects of epistemic and psychic recovery.

A core characteristic of I/indigenous-sponsored reeducation projects across various global contexts is the collective understanding that Ancestral Memory is an essential tool in the process (remembrance) of locating and leveraging what has been lost to memory (Baruti, 2015). We might define Ancestral Memory as the repository of recurring cultural forms, ancestral incarnations, cultural experiences, and imaginings through which is constructed specific kinds of historicity, performativity, and relationships to the remembered/ unremembered past. For I/indigenous peoples, these formations perpetuate the construction of their individual and collective selves through reinvoking and reinscribing heritage knowledge. With this cultural assumption embroidered in diverse array throughout I/ indigenous cultures, knowledge tends to be viewed as an instrument for collective coexistence; harmonizing praxis; and preserving, strengthening, and passing on heritage and shared cultural wealth.

\section{Conclusion}

Though I/indigenous groups continue to struggle against deculturalization processes that impact their lives and futures, the various existential threats are answered by rigorous, tireless campaigns of resistance that seek to interrogate, interrupt, and dismantle dominant metanarratives and hegemonic practices. As has been shared, holistic education, effective development, and progressive social transformation are all possible when I/indigenous knowledges, methodologies, and values are leveraged and applied to societal challenges. To be sure, proponents for educational equity and curriculum justice will likely continue to 
encounter deep resistance to efforts to interrogate, challenge, and dismantle dominant metanarratives around remembered history, knowledge production, and pedagogy. However, what must be understood is that this is a natural and expected aspect of the protracted struggle against deculturalization projects. As they rediscover, reassert, and reinscribe their resilient histories, languages, cultural rhythms, and ways of knowing, I/indigenous peoples strengthen their collective capacities to educate the future and to struggle against and transcend ongoing existential challenges.

\section{Further Reading}

Au, W., Brown, A. L., \& Calderón, D. (2016). Reclaiming the multicultural roots of U.S. curriculum: Communities of color and official knowledge in education. New York, NY: Teachers College Press.

Dunbar-Ortiz, R. (2014). An indigenous peoples' history of the United States. Boston, MA: Beacon Press.

Dei, G. J. S. (2018). Reframing blackness and black solidarities through anti-colonial and decolonial prisms. Cham, Switzerland: Springer.

Dei, G. J. S. (Ed.). (2017). Indigenous philosophies and critical education: A reader. New York, NY: Peter Lang.

Denzin, N. K., Lincoln, Y. S., \& Smith, L. T. (Eds.). (2008). Handbook of critical and indigenous methodologies. Thousand Oaks, CA: SAGE.

Esteva, G., \& Prakash, M. S. (1997). Grassroots post-modernism: Beyond human rights, the individual self, and the global economy. New York, NY: Peter Lang.

Fanon, F. (1968). The wretched of the earth. New York, NY: Grove Press.

Paraskeva, J. M. (2016). Curriculum epistemicide: Towards an itinerant curriculum theory. New York, NY: Routledge.

Paraskeva, J. M., \& Steinberg, S. R. (Eds.). (2016). Curriculum: Decanonizing the field. New York, NY: Peter Lang.

Tuhiwai Smith, L. (2012). Decolonizing methodologies: Research and indigenous peoples. London, UK: Zed Books.

Villegas, M., Neugebauer, S. R., \& Venegas, K. R. (Eds.). (2008). Indigenous knowledge and education: Sites of struggle, strength, and survivance. Cambridge, MA: Harvard Educational Review.

\section{References}

Asante, M. K. (2017). Revolutionary pedagogy: Primer for teachers of black children. Brooklyn, NY: Universal Write. 
Baldwin, J. A. (1980). The psychology of oppression. In M. K. Asante \& A. S. Vandi (Eds.), Contemporary black thought: Alternative analyses in social and behavioral science (pp. 95-110). Thousand Oaks, CA: SAGE.

Baldwin, J. A. (1984). African self-consciousness and the mental health of African-Americans. Journal of Black Studies, 15(2), 177-194.

Baldwin, J. A. (1985). Psychological aspects of European cosmology in American society: African and European cultures. The Western Journal of Black Studies, 9(4), 216-223.

Baldwin, J. A. (1989). The role of black psychologists in black liberation. Journal of Black Psychology, 16(1), 67-76.

Baruti, M. K. B. (2015). Sovereignty \& remembrance. Atlanta, GA: Akoben House.

Baruti, M. K. B. (2015). Kebuka! Remembering the middle passage through the eyes of our ancestors. Atlanta, GA: Akoben House.

Bhabha, H. K. (2004). The location of culture. London, UK: Routledge.

Bowles, S., \& Gintis, H. (1976). Schooling in capitalist America: Educational reform and the contradictions of economic life. New York, NY: Basic Books.

Brady, W. (1997). Indigenous Australian education and globalisation_<https://doi.org/10.1023/A: 1003077718880>. International Review of Education, 43(5/6), 413-422.

Carcamo, C. (2013). Judge upholds Arizona law banning ethnic studies classes_<https:// www.latimes.com/nation/la-xpm-2013-mar-12-la-na-nn-ff-ethnic-studies-arizona-20130312story.html>. Los Angeles Times.

Dei, G. J. S., Hall, B. L., \& Rosenberg, D. G. (Eds.). (2000). Indigenous knowledges in global contexts: Multiple readings of our world. Toronto, ON: University of Toronto Press.

Du Bois, W. E. B. (1903). The souls of black folk: Essays and sketches. New York, NY: Fawcett Press.

Du Bois, W. E. B. (1973). The education of Black people: Ten critiques, 1906-1960. (Aptheker, H., Ed.). New York, NY: Monthly Review Press.

Fanon, F. (1967). Black skin, white masks. New York, NY: Grove Press.

Goff, P. A., Eberhardt, J. L., Williams, M. J., \& Jackson, M. C. (2008). Not yet human: Implicit knowledge, historical dehumanization, and contemporary consequences < $<$ ttps://doi.org/ 10.1037/0022-3514.94.2.292>. Journal of Personality and Social Psychology, 94(2), 292-306.

Government of Ecuador. (2013). National development plan, national plan for good living 20132017: A better world for everyone_<https://www.planificacion.gob.ec/wp-content/uploads/ downloads/2013/12/Buen-Vivir-ingles-web-final-completo.pdf $>$. Quito: Republic of Ecuador.

Grande, S. (2015). Red pedagogy: Native American social and political thought. Lanham, MD: Rowman \& Littlefield. 
Haslam, N. (2006). Dehumanization: An integrative review_<https://doi.org/10.1207/ s15327957pspr1003 4>. Personality and Social Psychology Review, 10(3), 252-264.

Hawai'i Constitution <https://rb.hawaii.gov/constitution\#articlex>. (n.d.).

Kambon, K. (2003). Cultural misorientation: The greatest threat to the survival of the black race in the 21st century. Tallahassee, FL: Nubian Nation.

King, J. E. (2004). Culture-centered knowledge: Black studies, curriculum transformation, and social action. In J. A. Banks \& C. A. McGee Banks (Eds.), Handbook of research on multicultural education (2nd ed., pp. 349-378). San Francisco, CA: Jossey-Bass.

King, J. E., \& Swartz, E. E. (with Campbell, L., Lemons-Smith, S., \& López, E.). (2014). “Remembering" history in student and teacher learning: An Afrocentric culturally informed praxis. New York, NY: Routledge.

Kteily, N., Bruneau, E., Waytz, A., \& Cotterill, S. (2015). The ascent of man: Theoretical and empirical evidence for blatant dehumanization <https://doi.org/10.1037/pspp0000048>. Journal of Personality and Social Psychology, 109(5), 901-931.

Lim, S. Y. (2020). Speak Mandarin campaign_<https://eresources.nlb.gov.sg/infopedia/articles/ SIP 2013-07-04_122007.html>. Singapore Infopedia.

Limerick, N. (2020). Indigenous movements in Ecuador_<https://revista.drclas.harvard.edu/ book/indigenous-movements-ecuador $>$. ReVista: Harvard Review of Latin America.

McGregor, D. P. (2010). Statehood: Catalyst of the twentieth-century Kanaka 'Ōiwi cultural renaissance and sovereignty movement $\leq$ https://doi.org/10.1353/jaas.2010.0011>. Journal of Asian American Studies, 13(3), 311-326.

Reynolds, H. (2006). The other side of the frontier: Aboriginal resistance to the European invasion of Australia. Sydney, Australia: University of New South Wales Press.

Santos, B., de S. (2014). Epistemologies of the South: Justice against epistemicide. Boulder, CO: Paradigm.

Santos, B., de S. (2016). Epistemologies of the South and the future. From the European South: A Transdisciplinary Journal of Postcolonial Humanities, 1, 17-29.

Skutnabb-Kangas, T. (2013). Linguistic genocide in education-Or worldwide diversity and human rights? Hoboken, NJ: Taylor \& Francis.

Spring, J. (2010). Deculturalization and the struggle for equality: A brief history of the education of dominated cultures in the United States. Boston, MA: McGraw-Hill.

Spring, J. H. (2018). American education. Boston, MA: McGraw Hill Higher Education.

Thiong'o, N. (2009). Something torn and new: An African renaissance. New York, NY: Civitas Books.

United Nations. (2015). Transforming our world: The 2030 agenda for sustainable development_<https://sustainabledevelopment.un.org/post2015/transformingourworld/ publication>. Geneva, Switzerland: UN. 
United Nations Educational, Scientific and Cultural Organization. (2000, April 26-28). Dakar framework for action. Education for All: Meeting our collective commitments. World Forum on Education, Dakar, Senegal.

United Nations Educational, Scientific and Cultural Organization. (2017). Indigenous knowledge and practices in education in Latin America_<https://unesdoc.unesco.org/ark:/48223/ pf0000247754 eng >. Santiago, Chile: United Nations Educational and the Regional Office for Education in Latin America and the Caribbean.

Wilson, A. N. (1993). The falsification of Afrikan consciousness: Eurocentric history, psychiatry and the politics of white supremacy. Brooklyn, NY: Afrikan World Infosystems.

Woodson, C. G. (1933). The mis-education of the Negro. Washington, DC: Associated. 